\title{
ABSORPTION OF RADIOACTIVE IRON BY ANAEMIC INFANTS
}

BY

\author{
IAN D. RILEY \\ From Stobhill Hospital, Glasgow
}

(ReCEIVED FOR PUblication SePtember 25, 1959)

The oral administration of iron to anaemic infants often fails to restore the haemoglobin level as rapidly as it would in an adult. The reason for this failure could be either failure of absorption or failure to utilize the iron which had been absorbed, or deposition of all the iron in the tissue stores without any being incorporated in the haemoglobin. It was therefore decided to study the absorption and utilization of iron in anaemic infants and children using tracer quantities of the isotope ${ }^{59} \mathrm{Fe}$ administered orally.

\section{Method}

Three control and six anaemic infants and children were studied. Blood and marrow studies were made in all cases. The anaemic cases had a haemoglobin range of from $3 \cdot 0$ to $9 \cdot 6 \mathrm{~g}$.

\begin{tabular}{|c|c|c|c|c|c|}
\hline Controls & $\begin{array}{c}\% \text { of } \\
\text { Dose } \\
\text { Appearing } \\
\text { in Blood }\end{array}$ & $\begin{array}{c}\% \text { of } \\
\text { Absorbed } \\
\text { Iron } \\
\text { Appearing } \\
\text { in Blood }\end{array}$ & $\begin{array}{c}\% \text { of } \\
\text { Dose } \\
\text { Recovered } \\
\text { in Stool }\end{array}$ & $\begin{array}{c}\% \text { of } \\
\text { Dose } \\
\text { Absorbed }\end{array}$ & $\underset{\text { globin }}{\text { (g.) }}$ \\
\hline $\begin{array}{l}\text { J.N. } \\
\text { F.D. } \\
\text { J.F. }\end{array}$ & $\begin{array}{r}40 \cdot 0 \\
3 \cdot 7 \\
8 \cdot 7\end{array}$ & $\begin{array}{r}63 \cdot 5 \\
5 \cdot 8 \\
21 \cdot 7\end{array}$ & $\begin{array}{l}37 \\
37 \\
60\end{array}$ & $\begin{array}{l}63 \\
63 \\
40\end{array}$ & $\begin{array}{l}11 \cdot 0 \\
10 \cdot 8 \\
10 \cdot 8\end{array}$ \\
\hline \multicolumn{6}{|l|}{$\begin{array}{c}\text { Anaemic } \\
\text { Patients }\end{array}$} \\
\hline $\begin{array}{l}\text { W.A. } \\
\text { I.Mc.L. } \\
\text { F.O'D. } \\
\text { J.M. } \\
\text { M.D. } \\
\text { P.S. }\end{array}$ & $\begin{array}{r}4 \cdot 0 \\
31 \cdot 0 \\
6 \cdot 0 \\
4 \cdot 0 \\
15 \cdot 4 \\
20 \cdot 0\end{array}$ & $\begin{array}{l}40 \cdot 0 \\
50 \cdot 0 \\
40 \cdot 0 \\
11 \cdot 1 \\
16 \cdot 7 \\
23 \cdot 2\end{array}$ & $\begin{array}{r}90 \\
62 \\
85 \\
64 \\
8 \\
14\end{array}$ & $\begin{array}{l}10 \\
35 \\
15 \\
36 \\
92 \\
86\end{array}$ & $\begin{array}{l}9 \cdot 6 \\
8 \cdot 5 \\
8 \cdot 4 \\
9 \cdot 6 \\
4 \cdot 8 \\
3 \cdot 0\end{array}$ \\
\hline
\end{tabular}

Two microcuries of ${ }^{59} \mathrm{Fe}$ were given in $5 \mathrm{ml}$. of water which contained $100 \mathrm{mg}$. of ferrous sulphate or $30 \mathrm{mg}$. of iron. After oral administration of the dose, the faeces were collected for five days, and bulked. They were then homogenized in a mixer and an aliquot was counted in a well-type scintillation counter. Blood samples were taken on four occasions during the next fortnight into a mixture of potassium oxalate and sodium fluoride anticoagulant, and counted in the same apparatus. An aliquot of the dose was diluted and counted as a standard, so that the percentage of the dose excreted in the faeces and circulating in the blood stream could be calculated.

Blood volumes were determined in each case by the Evans blue technique (Muldowney, 1957). The highest figure obtained from the blood was added to that from the faeces, and the remaining percentage of the original dose was considered to have entered the tissue stores. In view of the difficulty of performing external body counting tests upon small infants this estimation was not attempted (Wetherley-Mein, Hutt, Langmead and Hill, 1956).

\section{Results}

The relation of four factors was studied, the degree of anaemia, the level of ${ }^{59} \mathrm{Fe}$ in the blood, its absorption and its utilization.

Blood Levels of ${ }^{59} \mathrm{Fe}$. Radioactivity was present in the blood in the first examinations (Fig. 1), on

\section{$\%$ in Blood v. Days after Administration}

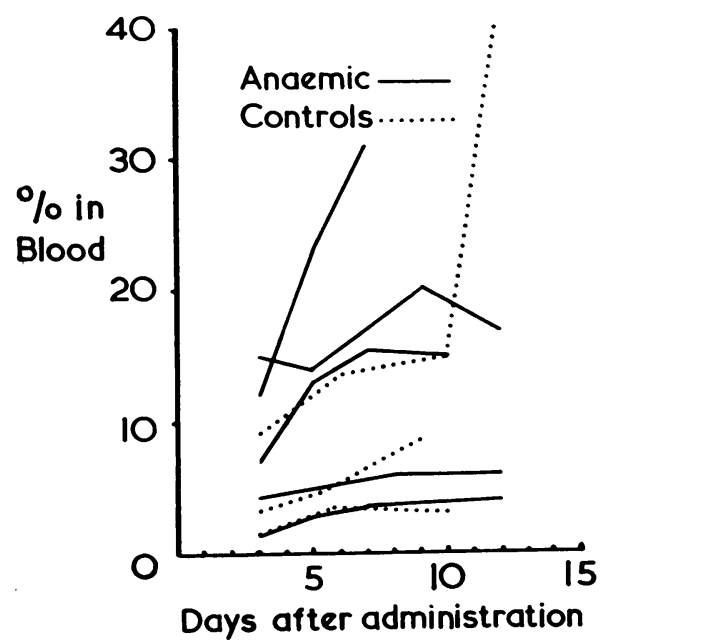

Fig. 1 -Showing rise in the percentage of the isotope administered appearing in blood up to a fortnight after administration. 
the third day and usually continued to rise steadily until the seventh day. This indicates that oral radioactive iron in tracer doses is rapidly incorporated in haemoglobin. This is in agreement with the findings of other workers.

Effect of Anaemia. The final level reached is directly related to the degree of anaemia present (Fig. 2) and the more severe the anaemia the higher the final level of the isotope in the blood.

Preliminary experiments were conducted using the blood level as a guide to absorption, but it now became apparent, as it had to other workers (Josephs, 1958) that blood levels are reliable as a measure of absorption only if utilization is complete, and this only occurs in the anaemias which follow haemorrhage and in the iron deficiencies of adults. Faecal excretion was therefore also estimated to give an iron balance (Dubach, Callender and Moore, 1948).

Hb. $v$ Maximum blood level.

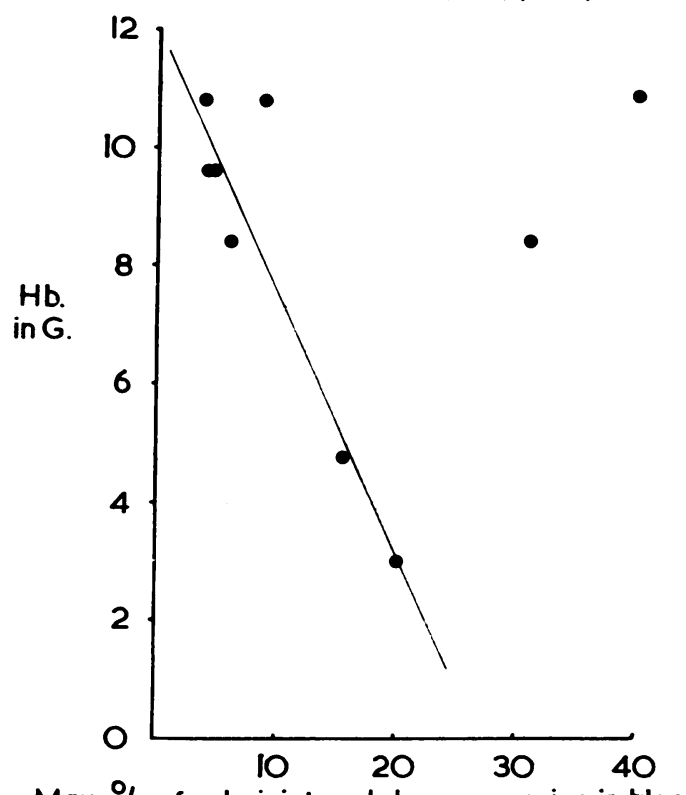

Max. \% of administered dose appearing in blood

FIG. 2.- Showing that the highest percentages of administered isotope detected in the blood were usually associated with the lowest haemoglobin levels.

Absorption. This was measured from the faecal excretion which was $37-60 \%$ of the dose administered in the controls, and $8-85 \%$ in the anaemic cases. The remainder of the dose administered which was not recovered in the faeces, was assumed to have been absorbed. This gave absorptions in the controls of $40-63 \%$ with a mean of $49 \%$, and in the anaemic cases of $10-92 \%$ with a mean of $45 \%$. These wide variations are in accord with the findings in the literature, where absorptions in controls vary from $1 \cdot 5-6 \cdot 5 \%$ to $17-69 \%$ (Peterson and Ettinger, 1953; Bothwell, Mallett, Oliver and Smith, 1955, quoted from a table by Josephs, 1958).

Inspection of the levels in the anaemic cases (Fig. 3) suggests that there may be two types of anaemic child represented, one with a low absorption and one with a high absorption. This is supported by the fact that the two cases with high absorptions also attained high blood levels of the isotope.

The effect of anaemia upon absorption is considered by most workers to produce increased absorption, but in the present series this was only observed in the two cases in which the diet had been deficient, and there was a decrease in the other cases as compared with the controls.

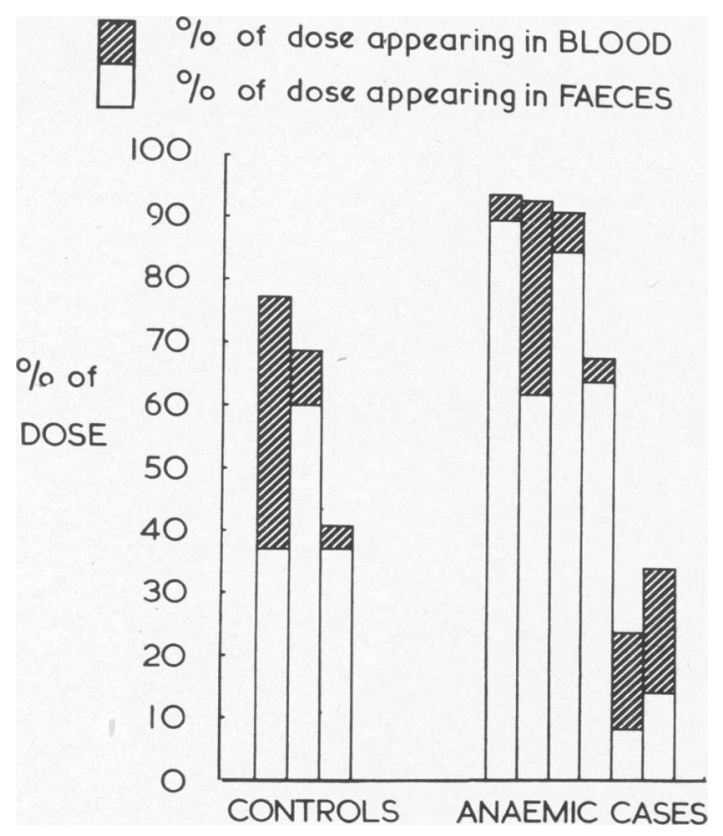

FIG. 3.-Showing the percentages of the isotope recovered from blood and faeces respectively.

Fate of Absorbed Iron. Once iron has been absorbed it may pass either to the tissues or be utilized in haemoglobin formation. Consequently a study of the factors likely to affect this distribution was made. 
Level of Isotope in the Blood. There is a direct relationship between this and the utilization of the absorbed iron. The higher the total uptake of ${ }^{59} \mathrm{Fe}$ the higher the percentage utilization of the absorbed iron (Fig. 4).

\section{Level of Isotope in Blood}

$$
\text { v. Utilization. }
$$

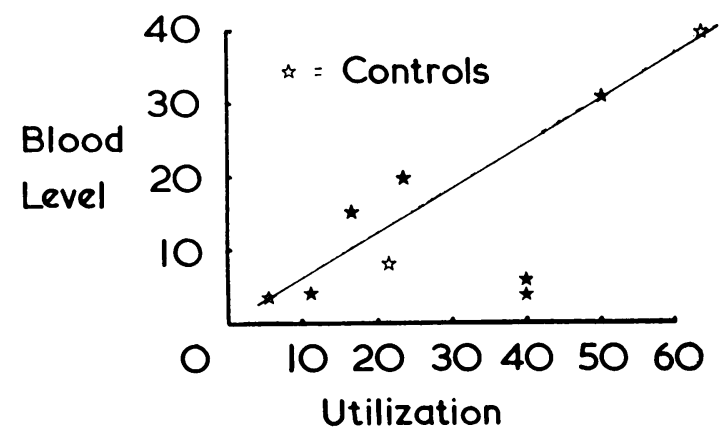

FIG. 4.-The relation between the amount of isotope appearing in the blood and the percentage of the iron absorbed which was utilized for haemoglobin formation.

Anaemia. This did not appear to affect directly the percentage utilization of absorbed iron.

Absorption. This on the other hand did show a slight relationship, a greater percentage of the absorbed iron being used for haemoglobin when the total absorption was low (Fig. 5).

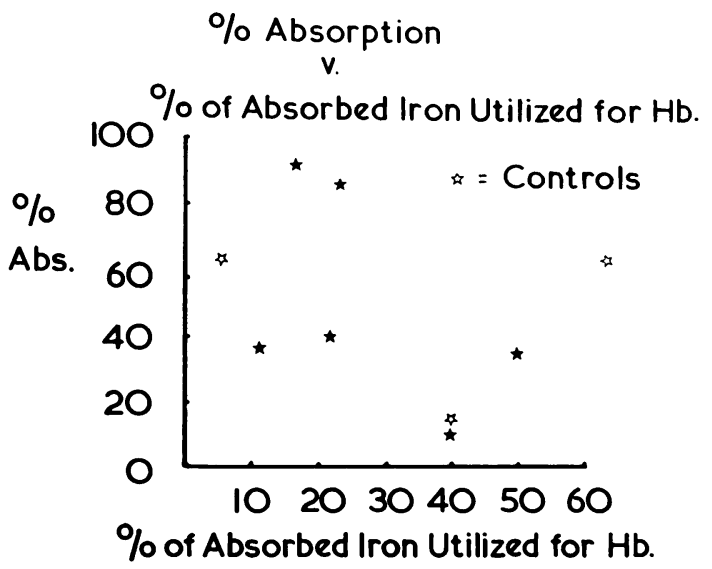

FIG. 5.-Demonstrates the percentage of iron, which, having been absorbed, is used for haemoglobin formation in relation to the total absorption of iron.
In assessing these results it is seen that radioactive iron enters the haemoglobin rapidly and rises to a steady level in about a week. The level ultimately attained, and the percentage of absorbed iron utilized, appear to depend upon the degree of anaemia rather than upon the total amount of iron absorbed. This is also suggested by the slightly higher utilization which occurs in cases of low absorption.

In the two types of anaemia which we have postulated in children, the high absorption and also the anaemia of one type, are both probably the result of depleted body iron stores, while in the other, the stores are probably normal, and the anaemia due in part to impaired absorption.

\section{Discussion}

The first investigations of anaemia in infancy showed that the blood picture was similar to that of iron deficiency anaemia in adults. This was the finding in all the anaemic cases of the present series who had hypochromia and microcytosis with the haemoglobin falling much lower than the red cells. Early studies of the effect of giving oral iron to these patients did not show as good results as were obtained in adults. There were in consequence many iron balance experiments performed (McCance and Widdowson, 1938; Hutchison, 1937) all of which showed that much more iron was absorbed than appeared in the red cells and that very little iron was excreted. It was deduced from this that large doses of iron were required for therapy. Studies of the plasma iron made about this time showed that it existed separately from the haemoglobin iron, and that it rose rapidly after ingestion of iron (Moore, Arrowsmith, Welch and Minnich, 1939).

Radioactive iron (Hahn, Bale, Ross, Balfour and Whipple, 1943) was given in tracer doses to dogs and was shown to be absorbed rapidly. This appeared to conflict with the results of the balance experiments but it is now thought that balance experiments conducted over a long period are not strictly comparable with those which study the effects of a single tracer dose. Clinical use of this method demonstrated that anaemic adults had higher absorptions than normal persons (Dubach et al., 1948). The appearance of tracer doses in the blood was the method which was employed in the preliminary experiments of the present series but it became apparent that this was a measure of iron absorption, only if all the iron was utilized for blood production, and this was manifestly not the case (Jeffrey, Freundlich, Jackson and Watson, 1955). It has been shown in adults that this only occurs 
after haemorrhage and in iron deficiency anaemia (Josephs, 1958). Balance experiments, in which the faeces were also estimated, were then introduced, and this was the method which we decided to employ. The uptake of intravenous doses of ${ }^{59} \mathrm{Fe}$ has also been studied by some workers (Dubach, Moore and Minnich, 1946) and is found to be increased if the iron stores are deficient, but the method would be dificult to use in children, and the placing of counters over the viscera would be inconvenient in infants.

Studies in children show that absorption is more complete than in adults (Darby, Hahn, Kaser, Steinkamp, Densen and Cook, 1947) and that it is more complete at 7 years than at 9 years. Contrary to former beliefs, absorption does occur at birth, but it may well be that utilization is slower (Oettinger, Mills and Hahn, 1954). Coeliac disease is associated with much impairment of absorption (Badenoch and Callender, 1954). We found this increase in absorption in childhood and we also found considerable variation between individual children. This has been found in the same patient on different occasions by some observers (Smith and Mallet, 1957).

Three sources of iron exist for children: the iron stores laid down at birth; the iron in the food; and therapeutic iron. The birth stores can be calculated, and may be deficient in small infants who grow rapidly, and in whom both tissue and haemoglobin iron may be inadequate in total quantity to supply the demands of growth, almost all of which have to be supplied from the iron present at birth (Smith, Rosello, Say and Yeya, 1955; Hahn et al., 1951).

The food iron is probably adequate in artificially fed infants, since Feuillen and Plumier' (1952) have shown that iron is acquired from utensils in the process of preparing the feed. Detailed studies of the absorption of food iron by children using ${ }^{59} \mathrm{Fe}$ have been made by Schulz and Smith (1958a) and they have again found greater, but variable, absorption of iron in children. They also studied the absorption of therapeutic iron (Schulz and Smith, 1958b) and found that anaemic children absorbed more than normal children and normal children more than normal adults, who are generally considered to absorb about $10 \%$ of the dose given. Their figures are lower than the present series in some instances, but other authors find higher rates. It is suggested that the present figures indicate two different types of anaemia in children, the one associated with a high uptake and the other with a lower figure. The possible sources of anaemia in childhood are: deficient stores at birth, or undue demand upon those stores, or impaired absorption.
It would appear that the production of haemoglobin and the rate of absorption are not closely related. Provided sufficient iron is available haemoglobin formation will occur. The two variables are the amount absorbed, and the retention and release of this iron by the tissues. Tissue store iron appears to be in two forms (Neerhout, Armstrong, Schulz and Smith, 1958), the one available for haemoglobin synthesis and the other not available. What the factor may be which determines availability has not been determined (Smith et al., 1955).

It appears that there may be two types of anaemia in small children, one associated with impaired absorption and slightly impaired utilization but normal tissue stores, and the other with depleted tissue stores which take up iron with great avidity, and utilize it with increased rapidity for haemoglobin synthesis.

\section{Summary}

The absorption and utilization of iron in anaemic infants and children was studied using tracer quantities of the isotope ${ }^{59} \mathrm{Fe}$.

It is suggested as a result of these investigations, that there may be two types of anaemia in children, the one associated with a low absorption and the other with a high absorption.

The chief factor regulating the appearance of radioactive iron in the blood appears to be the degree of anaemia, and the chief factor regulating absorption, the state of the body stores.

The author wishes to express his thanks to the Regional Physics Department of the Western Regional Hospital Board for the supply of the isotope, and to Dr. M. M. Bluhm and his colleagues of that department for a great deal of technical assistance.

\section{REFERENCES}

Badenoch, J. and Callender, S. T. (1954). Iron metabolism in steatorrhea; the use of radioactive iron in studies of absorption and utilization. Blood, 9, 123.

Bedwell, G. A., Patterson, J. and Suale, J. (1955). Estimation of Evans Blue in Plasma. J. clin. Path., 8, 61 .

Bothwell, T. H., Mallett, B., Oliver, R. and Smith, M. D. (1955). Inability to assess absorption of iron from plasma radio iron curves. Brit. J. Haemat., 1, 352.

Brokaw, K. F., Sedam, M. S. and Cassirer, A. M. (1942). The influence of diet on the physiologic anaemia of infants. $J$. Pediat., 21, 769.

Darby, W. J., Hahn, P. F., Kaser, M. M., Steinkamp, R. C., Densen, P. M. and Cook, M. B. (1947). The absorption of radioactive iron by children 7 to 10 years of age. J. Nutr., 33, 107.

Dubach, R., Callender, S. T. E. and Moore, C. V. (1948). Studies in iron transportation and metabolism VI. Blood, 3, 526.

, Moore, C. V. and Minnich, V. (1946). Studies in iron transportation and metabolism. J. Lab. clin. Invest., 31, 1201.

Feuillen, Y. M. and Plumier, M. (1952). Iron metabolism in infants. Acta paediat. (Uppsala), 41, 138.

Hahn, P. F., Bale, W. F., Ross, J. F., Balfour, W.M. and Whipple, G. H. (1943). Radioactive iron absorption by gastro-intestinal tract. J. exp. Med., 78, 169.

tract. others (1951). Iron metabolism in human pregnancy as studied with the radioactive isotope $\mathrm{Fe}^{59}$. Amer. J. Obstet. Gynec., 61, 477.

Hutchison, J. H. (1937). Studies in the retention of iron in childhood Arch. Dis. Childh., 12, 305.

Jeffrey, M. R., Freundlich, H. F., Jackson, E. B. and Watson, D. (1955). Absorption and utilization of radioactive iron in rheumatoid disease. Clin. Sci., 14, 395. 
Josephs, H. W. (1958). Absorption of iron as a problem in human physiology-a critical review. Blood, 13, 1 .

McCance, R. A. and Widdowson, E. M. (1938). The absorption and excretion of iron following oral and intravenous administration. J. Physiol. (Lond.), 94, 148.

Moore, C. V., Arrowsmith, W. R., Welch, J. and Minnich, V. (1939). Studies in iron transportation and metabolism (IV). J. clin. Invest., 18, 553.

Muldowney, F. P. (1957). The relationship of total red cell mass to lean body mass in man. Clin. Sci., 16, 163.

Neerhout, R. C., Armstrong, D. H., Schulz, J. and Smith, N. J. (1958). A quantitative study of the fate of recently absorbed food iron. A.M.A.J. Dis. Child., 95, 126.

Oettinger, L., Mills, W. B. and Hahn, P. F. (1954). Premature and full term infants. J. Pediat., 45, 302.
Peterson, R. E. and Ettinger, R. H. (1953).' Radioactive iron absorption in siderosis (haemochromatosis) of the liver. Amer. J. Med., 15, 518 .

Schulz, J. and Smith, N. J. (1958a). A quantitative study of the absorption of food iron in infants and children. A.M.A.J. Dis. Child., 95, 109.

Child (1958b). A quantitative study of the absorption of iron salts in infants and children. Ibid., $95,120$.

Smith, M. D. and Mallett, B. (1957). Iron absorption before and after partial gastrectomy. Clin. Sci., 16, 23.

Smith, N. J., Rosello, S., Say, M. B. and Yeya, K. (1955). Iron storage in the first five years of life. Pediatrics, 16, 166.

Sturgeon, P. (1956). Iron metabolism. Ibid., 18, 267.

Wetherley-Mein, G., Hutt, M. S. R., Langmead, W. A. and Hill, M. J. (1956) Radioactive iron studies in routine haematological practice. Brit. med. J., 1, 1445 .

\section{A P PENDIX}

\section{Clinical Details of Cases Studied}

\section{Controls}

J.McN., aged 5 years, was admitted with tuberculous meningitis from which he made a good recovery. He was under treatment with P.A.S. and I.N.A.H. at the time of the observations, and his haemoglobin was $11 \mathrm{~g}$. His birth weight was $6 \mathrm{lb}$. and his weight at the time of the experiment was $40 \mathrm{lb}$. His diet appeared to have been adequate.

F.D., aged 13 months, was a microcephalic admitted with bronchitis, his physique was normal and his intelligence only moderately impaired. His weight was $16 \mathrm{lb}$. and his birth weight was $6 \mathrm{lb}$. There was no obvious evidence of malnutrition and he took his feeds well, but it was possible that having been backward, feeding may have been difficult and therefore inadequate. His haemoglobin was $10.8 \mathrm{~g}$. at the time of the experiment which was started on the seventh day after admission.

J.F., aged 2 years, was admitted with a respiratory infection. She weighed $28 \mathrm{lb}$. and her birth weight was $7 \mathrm{lb}$. Her diet may have been inadequate, since mixed feeding was not instituted until 1 year of age.

\section{Anaemic Cases}

I.Mc.L., aged 14 years, was first admitted at 7 years with pallor and was found to have an iron deficiency anaemia with a haemoglobin of $2.5 \mathrm{~g}$. No adequate cause for this was found despite extensive investigations. The condition responded to oral iron but recurred on several occasions. Home conditions were poor and the diet was probably inadequate. This case differs somewhat from the others and may be considered atypical. His haemoglobin at the time of the experiment was $8.5 \mathrm{~g}$.

F.O'D., aged 18 months, was admitted on account of an upper respiratory infection and was found to have a haemoglobin of $8 \cdot 4 \mathrm{~g}$. His anaemia appeared to be due to three things: the fact that he was a premature baby weighing $3 \mathrm{lb} .11 \mathrm{oz}$. at birth, an attack of pneumonia at 6 months and delay in commencing mixed feeding until 1 year.

J.M., aged 12 months, was admitted on account of infantile eczema and transferred to the paediatric unit because of a cold in the head. His haemoglobin was $9.6 \mathrm{~g}$., he weighed $20 \mathrm{lb}$. and his birth weight was $8 \frac{1}{2} \mathrm{lb}$. $\mathrm{He}$ had no previous history of infection and the only factor to which his anaemia could be attributed was the difficulty in feeding sometimes encountered in cases of infantile eczema.

W.D., aged 18 months, was admitted on account of stomatitis. Her weight was $23 \mathrm{lb}$. and her birth weight $7 \mathrm{lb}$. She was found to have a haemoglobin of $9.6 \mathrm{~g}$. The cause of her anaemia was almost certainly nutritional as home conditions were poor.

The two remaining cases were those with the high uptakes and utilization.

M.D., aged 11 months, was admitted on account of her pallor. Her weight was $23 \mathrm{lb}$. and her birth weight $6 \frac{3}{4} \mathrm{lb}$. Her haemoglobin on admission was $4.8 \mathrm{~g}$. and the blood picture suggested a very severe iron deficiency. The cause of the anaemia in this case was almost certainly dietetic since she had been very difficult to feed. The response to oral treatment was immediate.

P.S., aged 6 years, weighed $31 \mathrm{lb}$. with a birth weight of $6 \mathrm{lb}$. He was admitted on account of pallor and his haemoglobin was $3.0 \mathrm{~g}$. on admission. He was a very wilful child who refused to eat meat in any form, and it was obvious that the largely carbohydrate diet upon which he had been fed, was the cause of his anaemia. His response to oral iron was immediate. 